\title{
CHANGES IN THE HEAT-RESISTANCE OF ASCOSPORES OF NEUROSPORA UPON GERMINATION ${ }^{1}$
}

\author{
Yamuna Lingappa and A. S. Sussman
}

\section{A B S T R A C T}

\begin{abstract}
Lincappa, Yamuna, and A. S. Sussman. (U. Michigan, Ann Arbor.) Changes in the heat-resistance of ascospores of Neurospora upon germination. Amer. Jour. Bot. 46(9): 671-678. IIlus. 1959.-A rapid loss in heat-resistance accompanies activation of ascospores of Neurospora tetrasperma after incubation at $27^{\circ} \mathrm{C}$. When activated spores are given a 5-min. "heat-flash" at $65^{\circ} \mathrm{C}$. after only $5 \mathrm{~min}$. at $27^{\circ} \mathrm{C}$., fully $\%$ fail to germinate. Such treatment, if administered $25 \mathrm{~min}$. after activation, results in the complete destruction of the spores. By contrast, when incubation at $27^{\circ} \mathrm{C}$. is not interposed, more than $1 / 2$ of the spores will germinate, even when they have been exposed to $65^{\circ} \mathrm{C}$. for $30 \mathrm{~min}$. Similar results were obtained with "heat-flashes" at 50 and $60^{\circ} \mathrm{C}$., although exposures of longer duration were required to affect the spores. Conidia respond very differently to "heat-flashes" in that germination is stimulated if they are provided after an incubation period at $27^{\circ} \mathrm{C}$. On the other hand, conidia are killed by short exposures to $60^{\circ} \mathrm{C}$., so that they are far more susceptible to such treatment than are ascospores. A study of the cardinal temperatures of germination revealed that the maximum is about $44^{\circ} \mathrm{C}$. for both conidia and ascospores. The maximum for the growth of two strains of $N$. tetrasperma and for one of $N$. crassa is between $40-45^{\circ} \mathrm{C}$.; however, another strain of the latter species grows at $45^{\circ} \mathrm{C}$. Dry heat was shown to be less effective than wet in activating ascospores. Removal of the exospore of ascospores results in the loss of considerable heat-resistance. In addition, the requirement for heat-activation is considerably mitigated in such spores, suggesting that the exospore, or an associated layer is the locus of the ascospore's heat-resistance.
\end{abstract}

IN MANY FUNGI, the conditions required for the germination of spores may be different from those that are optimal for prior, or subsequent, stages in development. This is shown very clearly when the cardinal temperatures for growth and germination are compared. Thus, Gäumann (1950) has reported that the spores of Clasterosporium carpophilum will germinate well between 9 and $27^{\circ} \mathrm{C}$., whereas there is a pronounced optimum for growth at $22^{\circ} \mathrm{C}$. Another striking illustration is that of the conidia of Erysiphe graminis which will germinate at $5-9^{\circ} \mathrm{C}$., although growth of the germ tube is not supported at these temperatures. Reciprocally, at $25^{\circ} \mathrm{C}$., germination is repressed but growth progresses well (Graf-Marin, 1934). In addition, there are several cases wherein the cardinal temperatures for the germination of different types of spores of the same organism may differ, as in some of the Uredinales (Doran, 1922; Arthur, 1929), Pseudopeziza ribis (Blodgett, 1935, 1936), and other organisms such as those discussed in the review by Sussman (1959).

The cases mentioned above involve only stages in the life-history of fungi in which clear morphological distinctions accompany the physiological ones revealed by the temperature optima. Yet, there are data which suggest that significant changes in metabolism may occur in certain fungal cells, even in the absence of morphological differences. Such an instance is that of the ascospores of Neurospora for which Goddard (1935) and Goddard and Smith (1938) suggested a qualitative

\footnotetext{
${ }^{1}$ Received for publication April 22, 1959.
}

change in metabolism after dormancy is broken. This suggestion has been supported by Sussman et al. (1956), Holton (1958) and Lingappa and Sussman (1959), who have shown that changes in the products of metabolism, endogenous substrates and content of cytochrome $\mathrm{C}$ mark the transition to the activated state in Neurospora spores. In addition, it is known that these cells require a heatshock in order to germinate (Shear and Dodge, 1927; Goddard, 1935) and are very resistant to extremes of temperature (Faull, 1930). For these reasons, it appeared possible that the heat-resistance of these cells might change in response to activation and the following experiments were designed to test this suggestion.

Materials AND Methods.-One-year-old ascospores of Neurospora tetrasperma, assembled as described by Goddard (1935), were used throughout these studies. Conidia of strains 394.4 and 394.5 , obtained through the kindness of Dr. B. 0 . Dodge, were subcultured on potato dextrose agar slants (PDA) and stored at $4{ }^{\circ} \mathrm{C}$. before they were crossed. The ascospores were washed repeatedly with distilled water, shaken in versene and washed as reported by Sussman (1954). Unless otherwise mentioned, the concentration of ascospores and conidia was standardized by the use of a blue filter (\#44) in a Klett-Summerson colorimeter.

Germination of conidia was accomplished at first by suspending them in $0.01 \%$ potato-dextrose medium, but later it was found that the conidia of both $N$. tetrasperma and $N$. crassa could germinate equally well in distilled water. Activation of ascospores was accomplished by exposure to $60^{\circ} \mathrm{C}$. for 

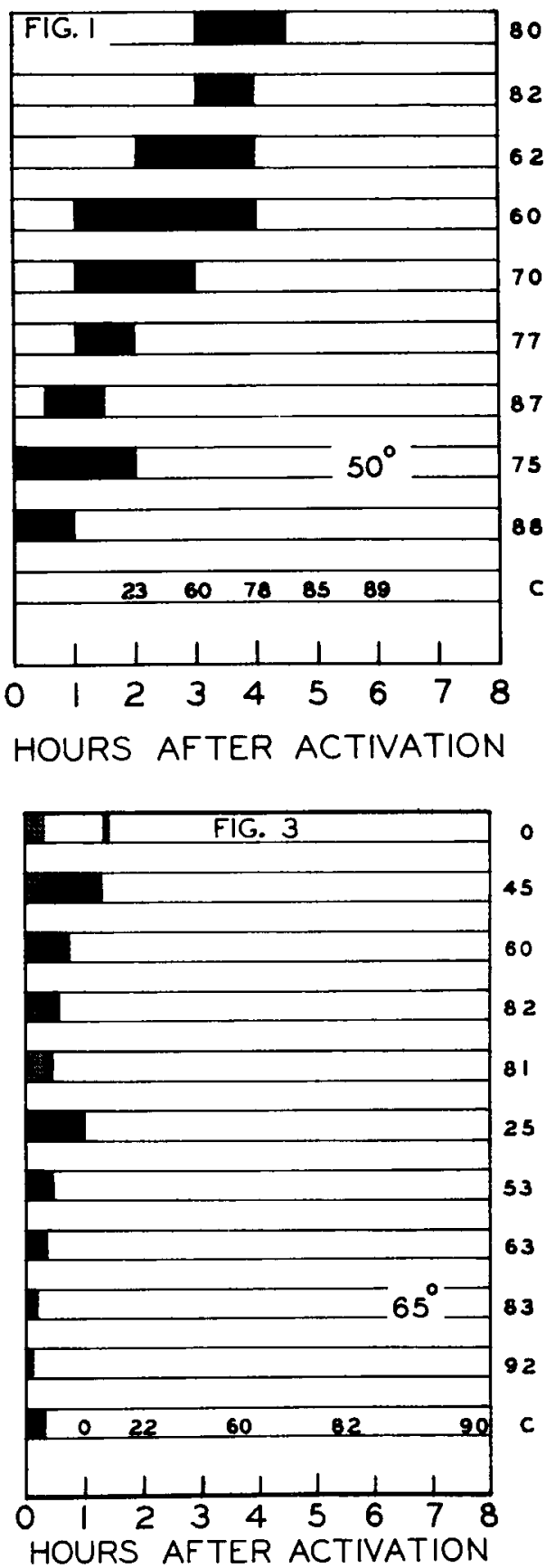
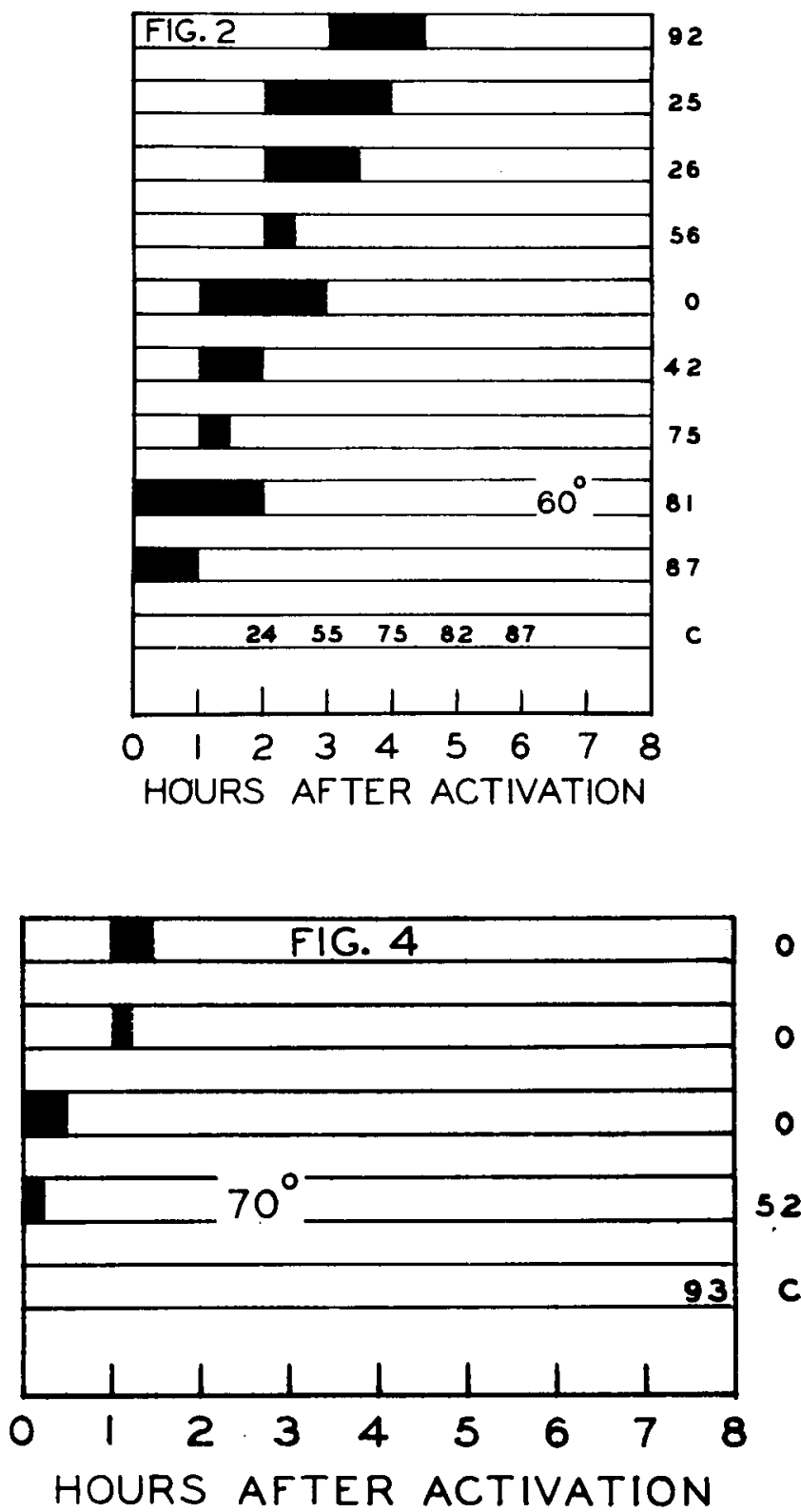

Fig. 1-4. Effect of exposure to high temperature upon germination of ascospores of Neurospora tetrasperma. Asco. spores were activated at $60^{\circ} \mathrm{C}$. for $20 \mathrm{~min}$., before the start of the experiment, except for some of those used as outlined in fig. 3. Periods of incubation at $27^{\circ} \mathrm{C}$. are indicated by the clear spaces and exposures to higher temperatures by the black ones. The letter $c$ along the ordinate refers to the control which was incubated throughout at $27^{\circ} \mathrm{C}$., and the numbers along this axis represent the percentage germination $8 \mathrm{hr}$. after the start of the incubation. The numbers within the control box are the germination percentages at the times indicated below on the abscissa.-Fig. 1. Heattreatment at $50^{\circ} \mathrm{C}$. - Fig. 2. Heat-treatment at $60^{\circ} \mathrm{C}$. - Fig. 3. Heat-treatment at $65^{\circ} \mathrm{C}$. The grey spaces indicate exposure to $60^{\circ} \mathrm{C}$. for $20 \mathrm{~min}$., and the black exposure to $65^{\circ} \mathrm{C}$. No activation-treatment, other than treatment at $65^{\circ} \mathrm{C}$., was provided the other spores used in this experiment. Exposures of 5, 10, 20,30 and 60 min.-Fig. 4. Heattreatment at $70^{\circ} \mathrm{C}$. 


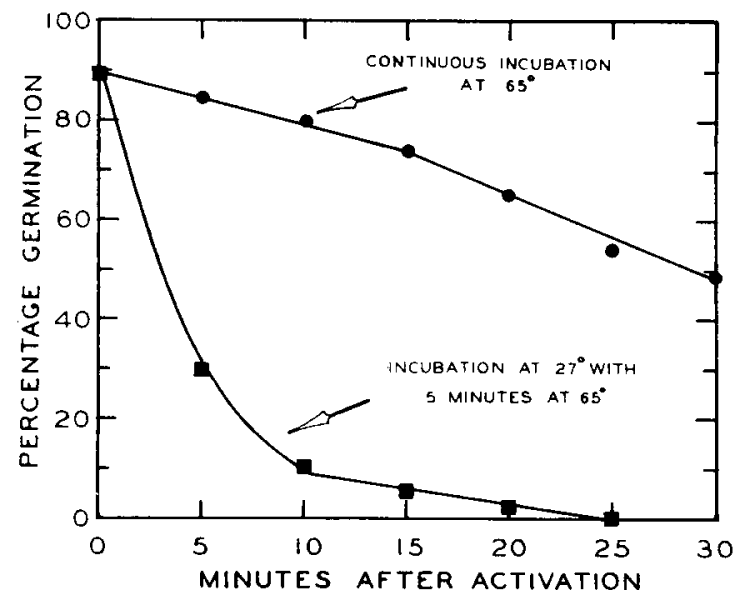

Fig. 5. Loss in heat-resistance of ascospores of Neurospora tetrasperma after brief incubation at $27^{\circ} \mathrm{C}$. Points indicated by squares were derived from experiments wherein ascospores were activated at $60^{\circ} \mathrm{C}$. for $20 \mathrm{~min}$. and incubated at $27^{\circ} \mathrm{C}$. for the times indicated on the abscissa, and exposed for $5 \mathrm{~min}$. to $65^{\circ} \mathrm{C}$. Thereupon, the spores were cooled and returned to $27^{\circ} \mathrm{C}$., and incubated for a total of $4 \mathrm{hr}$. The points represented by circles were obiained from experiments in which ascospores were exposed to $65^{\circ} \mathrm{C}$. immediately after activation, for periods of time from 5 to $30 \mathrm{~min}$. Incubation at $27^{\circ} \mathrm{C}$. was begun immediately after removal from the higher temperature, and the percentage of germination determined after $4 \mathrm{hr}$.

$20 \mathrm{~min}$. Treatment at other temperatures, after the activation period, was accomplished in a Dubnoff shaker in which the temperature was controlled to $\pm 1^{\circ} \mathrm{C}$. Incubation prior to germination was carried out on a rotary shaker maintained at $27^{\circ} \mathrm{C}$. At the end of this incubation period, ascospores or conidia were killed by a few drops of commercial formalin. At least 600 spores, in duplicate samples, were counted in determining the percentage germination.

Dry-heat treatment was administered to about $2 \mathrm{mg}$. of air-dry spores in flasks incubated in the Dubnoff shaker. At the end of certain periods, they were cooled to room temperature with tap water, $6 \mathrm{ml}$. of water was added and incubation resumed at the specified temperature.

Removal of the ribbed coats (exospores) of ascospores was accomplished by the method described by Lowry and Sussman (1958) who used $10 \%$ commercial Clorox for $30 \mathrm{~min}$. Hereafter, these spores will be referred to as "uncoated" spores.

In the experiments on growth, the standardization of inoculum was carried out as mentioned above except that sterile technique was employed. Growth tubes (Ryan, 1950), containing PDA or malt-dextrose agar, were used in these studies. Care was taken to maintain high humidity inside the incubators in which the growth tubes were placed in order to insure that the medium did not dry up during the course of the experiments. Growth was measured every $12 \mathrm{hr}$. and the average of samples in triplicate was used. Rarely, abnormal growth was observed in a tube, in which case the sample was discarded.

Results. - Interrupted heat-treatments. - As stated above, ascospores are normally induced to germinate by a short heat-shock at $60^{\circ} \mathrm{C}$., followed by incubation at $27^{\circ} \mathrm{C}$. Changes in heat-resistance were studied by means of experiments wherein ascospores were exposed to temperatures between 50 and $70^{\circ} \mathrm{C}$. at various times after activation. Controls in all cases were spores activated under the same conditions as the experimental samples and incubated continuously at $27^{\circ} \mathrm{C}$. The results of these experiments are provided in fig. 1-4 which show that after $\mathrm{l} \mathrm{hr}$. of incubation at $27^{\circ} \mathrm{C}$., a marked decrease in heat-resistance has occurred in activated ascospores. This is particularly true when the cells are exposed to temperatures greater than $50^{\circ} \mathrm{C}$., although there is an effect at this temperature as well. Thus, even $2 \mathrm{hr}$. at $60^{\circ} \mathrm{C}$. reduces germination by only $10 \%$, but such treatment, after the spores have been kept at $27^{\circ} \mathrm{C}$. for $1 \mathrm{hr}$., prevents germination entirely. When incubation at $27^{\circ} \mathrm{C}$., after activation, is carried out for $2 \mathrm{hr}$., treatments as short as $30 \mathrm{~min}$. at $60^{\circ} \mathrm{C}$. have a marked effect. It should be noted, in considering the latter data, that $23 \%$ of the spores had germinated in the controls at the end of $2 \mathrm{hr}$. (fig. 1-3), consequently, any heat-treatment administered after this time, would not be expected to affect this background level of germination.

When the temperature to which activated ascospores are exposed is increased, the duration of the treatment required to affect germination adversely is decreased. For example, when incubation at $27^{\circ} \mathrm{C}$. for $1 \mathrm{hr}$. is interrupted by as little as a 5-min. "heat-flash" at $65^{\circ} \mathrm{C}$., germination is completely stopped. Yet, exposure to the latter temperature for twice as long, if done immediately following activation, results in only a slight reduction in germination (fig. 3). Similar results were obtained when ascospores were heated at $70^{\circ} \mathrm{C}$., although a significant decline in germination occurred as a result of treatment for $15 \mathrm{~min}$., even in the absence of an incubation period at $27^{\circ}$.

The kinetics of the loss in heat-sensitivity was studied by providing a "heat-flash" of 5-min. duration at $65^{\circ} \mathrm{C}$. to cells that had been incubated at $27^{\circ} \mathrm{C}$. for periods up to $30 \mathrm{~min}$. after activation. After the heat-treatment, the cells were reincubated at $27^{\circ} \mathrm{C}$., and the percentage of germination determined as before and plotted in fig. 5. Another set of spores was maintained at $65^{\circ} \mathrm{C}$. continuously, for times up to $30 \mathrm{~min}$. after activation, and then placed at $27^{\circ} \mathrm{C}$. and their germination determined. Strikingly, even 5-min. incubation at the lower temperature results in the loss of resistance to $65^{\circ} \mathrm{C}$. in about $\%$ of the cells. After $25 \mathrm{~min}$. at $27^{\circ} \mathrm{C}$, the capacity to resist the high-temperature treatment is lost by all of the ascospores. By con- 


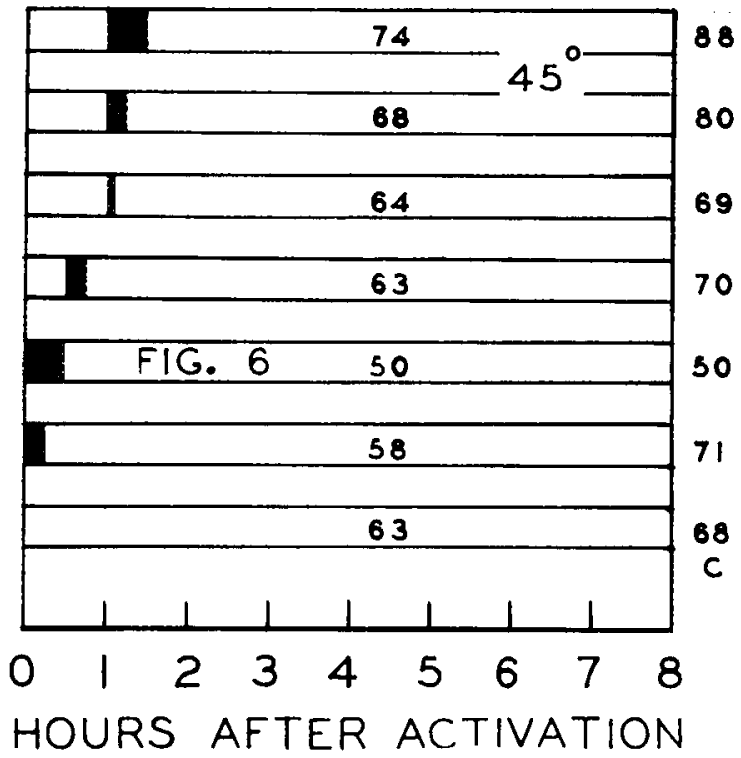

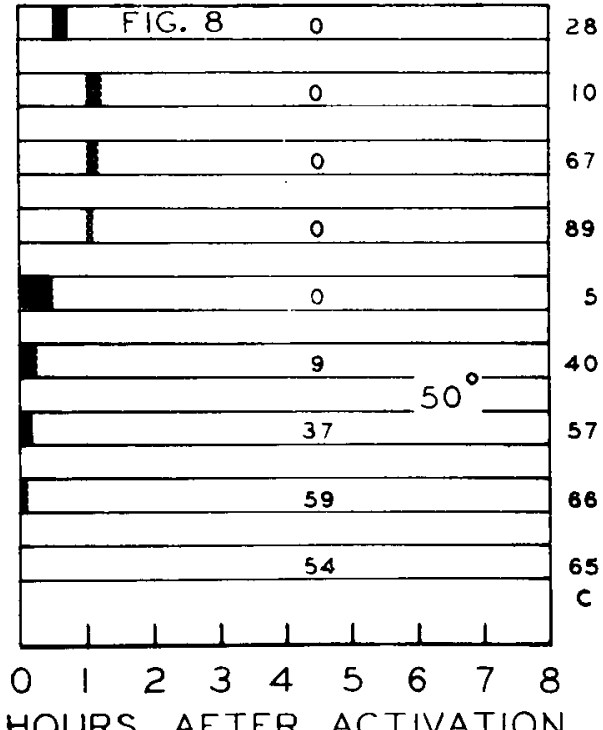
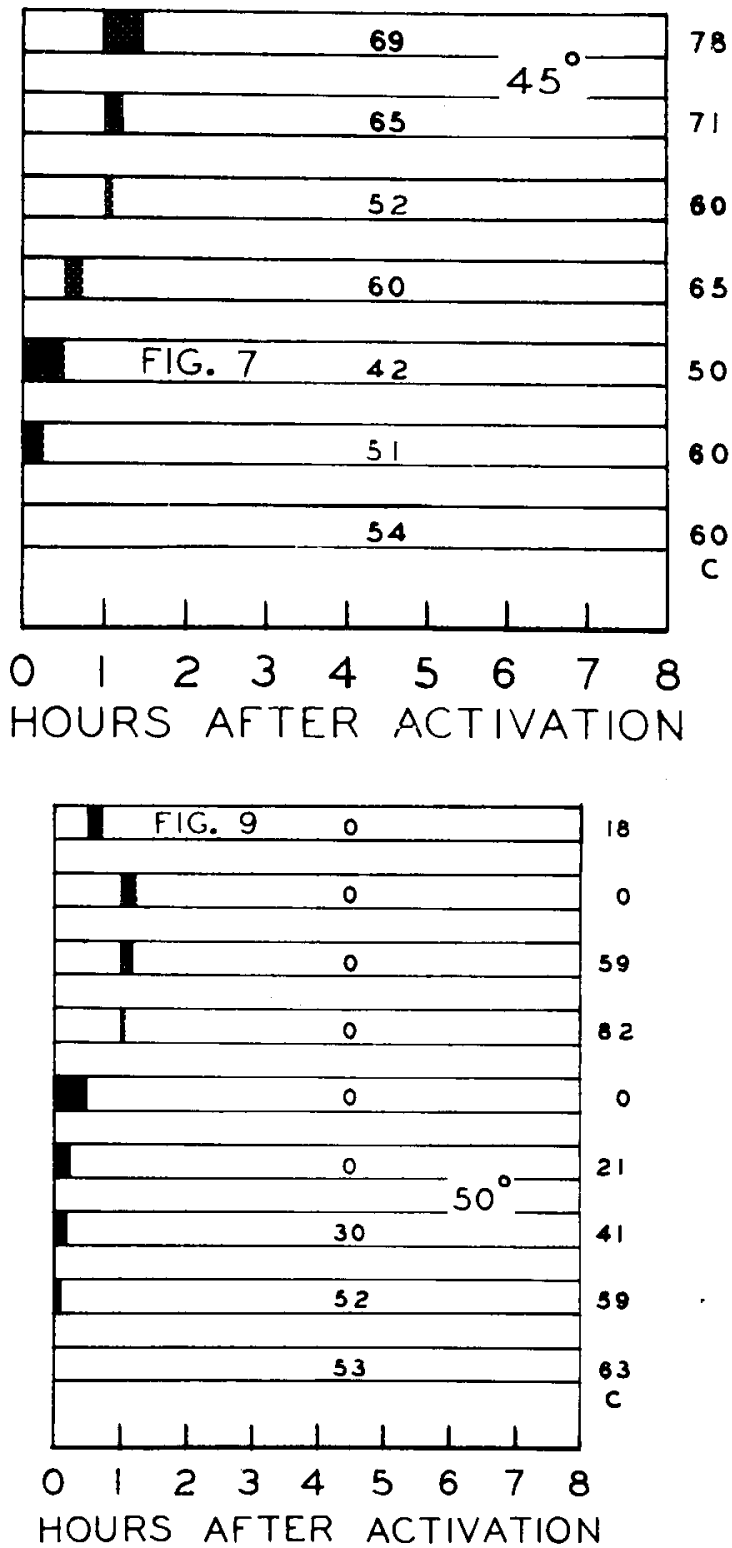

Fig. 6-9. Effect of exposure to high temperatures upon germination of conidia of Neurospora tetrasperma. Periods of incubation at $27^{\circ} \mathrm{C}$. are indicated by the clear spaces and exposures to higher temperatures by the black. The letter $c$ along the ordinate refers to the control which was incubated throughout at $27^{\circ} \mathrm{C}$. and the numbers along this axis represent the percentage of germination $8 \mathrm{hr}$. after the start of incubation. The numbers within the control box are germination percentages at the times indicated below on the abscissa.-Fig. 6 . Heat-treatment at $45^{\circ} \mathrm{C}$. with strain 394.5. Exposures of 5,15 and $30 \mathrm{~min}$. were given.-Fig. 7. Heat-treatment at $45^{\circ} \mathrm{C}$. with strain 394.4 . The same exposure periods as above were used.-Fig. 8. Heat-treatment at $50^{\circ} \mathrm{C}$. with strain 394.5 . Exposures of $5,10,15$ and $30 \mathrm{~min}$. were given.-Fig. 9. Heat-treatment at $50^{\circ} \mathrm{C}$. with strain 394.4 . The same exposure periods as in the experiments outlined in fig. 8 were used.

trast, spores that are incubated continuously at $65^{\circ} \mathrm{C}$. after being activated lose their heat-resistance much more gradually. Thus, more than $50 \%$ of them germinate after $25 \mathrm{~min}$. exposure to $65^{\circ} \mathrm{C}$., followed by incubation at $27^{\circ} \mathrm{C}$.

Long periods of exposure to a temperature at which ascospores would be activated $\left(60^{\circ} \mathrm{C}\right.$. $)$ were tried. Incubation of dormant cells for as long as
$4 \mathrm{hr}$. at this temperature, followed by $8 \mathrm{hr}$. at $27^{\circ} \mathrm{C}$., resulted in the germination of $30 \%$ of the spores. However, germination was never observed to occur while the spores were at the elevated temperature, in spite of the fact that the usual incubation period of $3 \mathrm{hr}$. at $27^{\circ} \mathrm{C}$. suffices to effect complete germination.

Conidial suspensions also were given "heat- 
flashes" of different duration at 45 or $50^{\circ} \mathrm{C}$., before and after incubation at $27^{\circ} \mathrm{C}$., and the percentage of germination calculated. As the results in fig. 6-9 reveal, prior incubation at the lower temperature does not render conidia of either strain of $N$. tetrasperma more sensitive to high temperatures. In fact, when they are treated in this way, the percentage of germination at the end of $8 \mathrm{hr}$. was usually increased. Thus, in strain 394.5, 30 min. exposure to $45^{\circ} \mathrm{C}$., an hour after incubation began, resulted in an increase of $20 \%$ in the percentage of germination over that of the control (fig. 6). Similar results were obtained with conidia of strain 394.4 , as the data in fig. 7 show. In general, these data paralleled those obtained when conidia were subjected to $50^{\circ} \mathrm{C}$., except that germination is delayed beyond $4 \mathrm{hr}$. in the latter instance (fig. 8, 9). This delay is greater when spores are first incubated at $27^{\circ} \mathrm{C}$. than when they are exposed to the higher temperature directly. However, a stimulatory effect upon conidial germination was demonstrable at $50^{\circ} \mathrm{C}$., as well as at $45^{\circ} \mathrm{C}$., except that the optimal effect was obtained in only $5 \mathrm{~min}$. The inhibitory effect of such treatment is greatest when conidia are subjected to high temperatures prior to incubation at $27^{\circ} \mathrm{C}$. Thus, the germination of strain 394.4 is completely stopped by $30 \mathrm{~min}$. treatment at $50^{\circ} \mathrm{C}$., while those of strain 394.5 are influenced almost as much. The same effect is apparent at $45^{\circ} \mathrm{C}$. but is less marked. Parallel experiments carried out with 5-min. "heatflashes" at $60^{\circ} \mathrm{C}$. resulted in the complete prevention of germination, no matter when the treatment was administered.

Cardinal temperatures for growth and germination.-Ascospores were activated in suspension, as described previously, and then were spread upon the surface of PDA in Petri dishes and incubated at various temperatures. Germination was fastest and most complete at $27^{\circ} \mathrm{C}$., although more than $1 / 2$ of the spores germinated at $44^{\circ} \mathrm{C}$. (table 1 ). On the other hand, no germination occurred at temperatures above $44^{\circ} \mathrm{C}$. The limit for the germination of ascospores is about $5^{\circ} \mathrm{C}$. since only

Table 1. Germination of ascospores of Neurospora tetrasperma at different temperatures; dashes indicate no counts were made

\begin{tabular}{cccccc}
\hline \hline $\begin{array}{c}\text { Time of } \\
\text { incubation } \\
\text { (hr.) }\end{array}$ & \multicolumn{5}{c}{ Percentage germination at: } \\
\cline { 2 - 6 } & $5^{\circ} \mathrm{C}$. & $9^{\circ} \mathrm{C}$. & $27^{\circ} \mathrm{C}$. & $44^{\circ} \mathrm{C}$. & $45^{\circ} \mathrm{C}$. \\
2 & 0 & 0 & 23 & 0 & 0 \\
4 & 0 & 0 & 89 & 0 & 0 \\
6 & 0 & 0 & 92 & 45 & 0 \\
8 & 0 & 0 & 96 & 53 & $0^{* 1}$ \\
24 & 0 & 11 & - & - & $0^{: 1}$ \\
48 & 0 & 23 & - & - & $0^{\prime \prime}$ \\
72 & 8 & - & - & - & 0
\end{tabular}

"A few germ buds appeared but did not progress to form a germ tube. a few spores germinated at this temperature after 3 days.

The temperature-maxima for the growth of the 2 strains of $N$. tetrasperma, as well as for 2 of $N$. crassa, were also studied. Inocula from the several sources were prepared and incubated at different temperatures in growth tubes on PDA. None of the strains of $N$. tetrasperma used grew above $40^{\circ} \mathrm{C}$. and growth was greatly restricted at this temperature (table 2). This was so despite the excellent

TABLE 2. Growth of Neurospora at different temperatures. Readings represent averages of the growth in $\mathrm{mm}$. of triplicate samples during a 24-hr. period; the figures in parentheses are the germination percentages determined from parallel cultures on PDA in Petri plates

Growth in mm. at:

Source of inoculum $\quad \overline{35^{\circ} \mathrm{C} .40^{\circ} \mathrm{C} .44^{\circ} \mathrm{C} .45^{\circ} \mathrm{C} 46^{\circ} \mathrm{C}}$

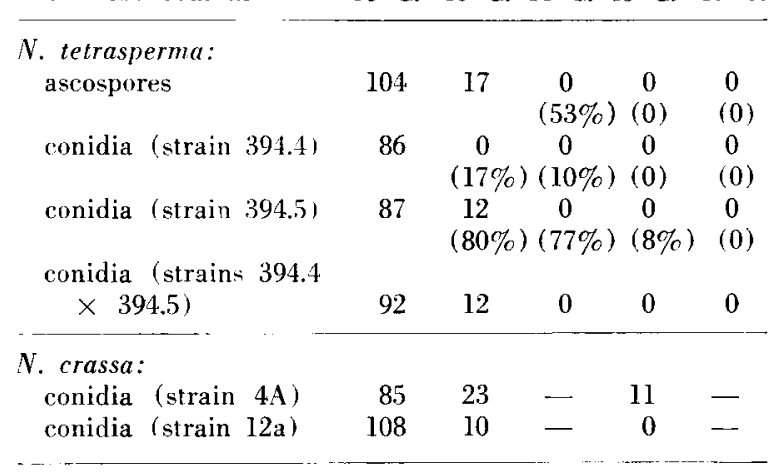

germination of conidia of strain 394.5 even at $44^{\circ} \mathrm{C}$., so that growth itself was affected and not simply germination. The same is true, to a lesser extent, for strain 394.4 , inasmuch as $10 \%$ germination was noted at $44^{\circ} \mathrm{C}$., and for mycelium produced from ascospores in which $53 \%$ germination occurred. The most resistant of the strains tested was $4 \mathrm{~A}$ of $N$. crassa, which grew slowly at $45^{\circ} \mathrm{C}$., whereas strain $12 \mathrm{a}$ has a maximum temperature for growth comparable to that for $N$. tetrasperma.

Effect of removal of exospore upon heat-resistance and activability. - The work of Lowry and Sussman (1958) has disclosed that the wall of ascospores of $N$. tetrasperma consists of 3 principal layers. The outermost one, or exospore, is characterized by its longitudinal striations which comprise the "nerves" which give the organism its name. This wall layer can be removed, by the use of Clorox, with no apparent effect upon the viability of the cell or upon the structure of the parts which remain after such treatment. Consequently, it was possible to study the effect of the removal of the exospore upon the heat-resistance and response to activation of ascospores.

Heat-resistance was studied first by subjecting "uncoated" ascospores to "heat-flashes" of the kind used above for the untreated cells. However, when such spores were heat-activated at the usual tem- 
perature $\left(60^{\circ} \mathrm{C}.\right)$, very little germination was obtained. This suggested, therefore, that the optimal conditions for activating "uncoated" spores had to be defined. Therefore, they were exposed to several temperatures for varying periods and the percentage of germination was determined. As the results in table 3 disclose, the optimal temperature for

TABLE 3. Effect of wet and dry heat upon the dormancy of ascospores of $N$. tetrasperma, from which the exospore had been removed; after heat-treatment all samples were incubated at $27^{\circ} \mathrm{C}$. for $4-5 \mathrm{hr}$. in water. Dashes indicate that no readings were made

\begin{tabular}{|c|c|c|c|c|}
\hline \multirow[b]{3}{*}{ Temperature } & \multicolumn{4}{|c|}{ Percentage germination } \\
\hline & \multicolumn{4}{|c|}{ Duration of heat-treatment $(\mathrm{min}$.$) :$} \\
\hline & 5 & 10 & 15 & 20 \\
\hline \multicolumn{5}{|l|}{ Wet-heal: } \\
\hline $60^{\circ} \mathrm{C}$ & 10 & 14 & 15 & 7 \\
\hline $50^{\circ} \mathrm{C}$ & 50 & 60 & 53 & 30 \\
\hline $45^{\circ} \mathrm{C}$ & 30 & 34 & 49 & 33 \\
\hline $40^{\circ} \mathrm{C}$ & 26 & 32 & 34 & 40 \\
\hline $35^{\circ} \mathrm{C}$ & 26 & 30 & 32 & 35 \\
\hline $30^{\circ} \mathrm{C}$ & 23 & 26 & 29 & 34 \\
\hline $27^{\circ} \mathrm{C}$ & \multicolumn{4}{|c|}{$21:$} \\
\hline $21^{\circ} \mathrm{C}$ & \multicolumn{4}{|c|}{$12^{\prime \prime}$} \\
\hline Dry-heat: & & & & \\
\hline $60^{\circ} \mathrm{C}$ & 11 & 14 & $-\ldots$ & 11 \\
\hline $50^{\circ} \mathrm{C}$. & 25 & 15 & - & 11 \\
\hline $45^{\circ} \mathrm{C}$. & 39 & 47 & - & 34 \\
\hline $40^{\circ} \mathrm{C}$. & 27 & 27 & - & 22 \\
\hline $35^{\circ} \mathrm{C}$. & 24 & 27 & - & 18 \\
\hline
\end{tabular}

"Ascospores were continuously incubated at $27^{\circ} \mathrm{C}$.

"Ascospores were continuously incubated at $21^{\circ} \mathrm{C}$.

activation of "uncoated" ascospores is about $50^{\circ} \mathrm{C}$. Moreover, significant activation is accomplished even at $30^{\circ} \mathrm{C}$., and some spores germinated with no treatment other than incubation at $27^{\circ} \mathrm{C}$. or $21^{\circ} \mathrm{C}$., so that the requirement for heat-activation has been considerably mitigated by the removal of the exospore. This was shown in another way by the use of dry heat instead of wet as in the previous experiments. The data in table 3 show that "uncoated" ascospores are activated optimally at $45^{\circ} \mathrm{C}$. by dry heat, although the total amount of germination is lower than when wet heat is used.

In contrast, the untreated ascospores were activated to a maximum of only $17 \%$ when dry heat at $60^{\circ} \mathrm{C}$. was used (table 4$)$. That the spores were not killed by this treatment was shown by the fact that subsequent exposure to $60^{\circ} \mathrm{C}$., in water, resulted in activation to a degree almost equivalent to that in controls exposed only to wet heat. It should be pointed out that dry heat at $50^{\circ} \mathrm{C}$. or $40^{\circ} \mathrm{C}$. was totally ineffective in breaking the dormancy of these cells.

Discussion AND CONCLusions.-To the list of changes which occur upon the disruption of the dormancy of ascospores of Neurospora can now
TABle 4. Effect of wet and dry heat at $60^{\circ} \mathrm{C}$. upon the dormancy of ascospores of $N$. tetrasperma; the spores were suspended in dist. water after the heat-treatment and incubated at $27^{\circ} \mathrm{C}$.

\begin{tabular}{ccc}
\hline $\begin{array}{c}\text { Time of heating } \\
\text { (min.) }\end{array}$ & $\begin{array}{c}\text { Percentage germination } \\
\text { Dry-heat }\end{array}$ & \begin{tabular}{c} 
Wet-heat \\
\cline { 2 - 2 }
\end{tabular} \\
\hline 5 & 1 & 73 \\
10 & 2 & 85 \\
15 & 3 & 87 \\
20 & 7 & 79 \\
25 & 10 & 76 \\
30 & 17 & 76 \\
45 & 6 & 75 \\
\hline
\end{tabular}

be added loss in heat-resistance. Evidence of this change is found within $5 \mathrm{~min}$. after activation, and the loss of such resistance is almost complete within $1 / 2 \mathrm{hr}$. thereafter, that is, at least $90 \mathrm{~min}$. before any morphological change is perceptible. Some hint as to the site of the ascospore's heat-resistance is furnished by the experiments with "uncoated" spores. The diminished resistance of such cells to high temperatures (table 3) and their activation even at temperatures as low as $30^{\circ} \mathrm{C}$., suggest that the exospore, or an associated structure, is removed or altered by Clorox and is responsible for the thermal-tolerance of ascospores. These observations recall the fact mentioned by Faull (1930) and Dodge (1930) that asci from certain crosses of Neurospora yielded ascospores that germinated without being heat-activated. It would be pertinent to determine whether there is any difference between the wall of these spores and that of cells requiring heat-treatment.

Previous work has shown that although activation occurs at $60^{\circ} \mathrm{C}$., the subsequent steps which culminate in germination do not proceed unless the spores are incubated at lower temperatures (Lingappa and Sussman, 1959). Moreover, these workers showed that the utilization of the ascospore's pool of soluble carbohydrates was slower at the higher temperature than at $27^{\circ} \mathrm{C}$. These data are complemented by the results of the experiments reported herein which show that germination never occurs if spores are kept at $60^{\circ} \mathrm{C}$., even though viability is retained. Inasmuch as loss in heatsensitivity has been shown to be a concomitant of activation, the fact that short periods of incubation at $27^{\circ} \mathrm{C}$. are required before such a change occurs is further evidence for the necessity of incubation at moderate temperatures.

A requirement for incubation at a temperature lower than that which breaks dormancy appears to be general among organisms which require such treatment. This is true for urediospores of Phrag. midium mucronatum (Cochrane, 1945), spores of Ustilago striieformis (Kreitlow, 1943), as well as for several other organisms listed by Sussman (1959). 
The several stages in the life-cycle of Neurospora have temperature-maxima that differ markedly. Ascospores, of course, are the most resistant, for not only do they survive $4 \mathrm{hr}$. at $60^{\circ} \mathrm{C}$. but they are activated, if an incubation period at $27^{\circ} \mathrm{C}$. is not interposed. These observations confirm the heat-resistance of ascospores which was studied in detail by Faull (1930), who reported that they survived heating for more than $4 \mathrm{hr}$. at $50^{\circ} \mathrm{C}$. Conidia, on the other hand, are killed by 5 -min. exposure to $60^{\circ} \mathrm{C}$., so that they are much more susceptible to injury by high-temperatures than are ascospores. By contrast, Faull showed that conidia survived exposures to $-170^{\circ} \mathrm{C}$. when dry almost as well as did ascospores. Judging from the temperature-maximum for the growth of the mycelium of $N$. tetrasperma, the vegetative phase in the lifehistory is the least resistant to high temperatures. Thus, in this case, none of the strains tested grew at temperatures above $40^{\circ} \mathrm{C}$., even though both ascospores and conidia germinated in high percentage at $44^{\circ} \mathrm{C}$. Despite the difference in heat-resistance of ascospores and conidia discussed above, their temperature-maxima for germination are ábout equivalent. In fact, those of conidia of strain 394.5 of $N$. tetrasperma and of strain 4A of $N$. crassa are higher than that for ascospores. The explanation of this seeming paradox lies in the change in heat-resistance of ascospores within a short time after germination, as discussed above. That strain- and specific differences in heat-resistance may occur is also pointed up by these data, inasmuch as strain 394.5 of $N$. tetrasperma is more resistant than 394.4, and strain $4 \mathrm{~A}$ of $N$. crassa is the most resistant of all those tested. On the other hand, there is no interaction between the strains of $N$. tetrasperma when they are crossed, in that the rate of growth of the mycelium derived from this cross is equivalent to that of the most resistant of the two.

The lesser effect of dry heat, as compared with that of wet, upon the time required for germination, has been observed previously in $N$. crassa (Faull, 1930). Similarly, Tsaugi (1933) found that oospores of Sclerospora graminicola remained viable at $60^{\circ} \mathrm{C}$. when dry, but that they were killed in water. Furthermore, as was mentioned above, Faull also showed that ascospores and conidia subjected to -170 to $-190^{\circ} \mathrm{C}$. survived longer when dry than wet, thereby extending the conclusion discussed above to include extreme cold. The present results are in agreement in that only slight activation of ascospores is induced by dry-heat. On the other hand, there are reports that germination is stimulated in Phragmidium mucronatum under these conditions (Cochrane, 1945), so that the conclusion cannot be generalized.

A similarity between ascospores and conidia involves their increased germination after heat-treatment. The response of ascospores to such treatment is well known but that of conidia was called attention to only recently by Ishii and Miyamota (1954). These workers reported that exposure of conidia of $N$. sitophila to $35-37^{\circ} \mathrm{C}$. for $\mathrm{I}-3 \mathrm{hr}$. induced increased germination. The results in fig. 6-9 corroborate these findings and disclose that 5 min. at $50^{\circ} \mathrm{C}$. or $30 \mathrm{~min}$. at $45^{\circ} \mathrm{C}$. have a stimulatory effect. However, these experiments, as well as those of Ishii and Miyamoto, reveal that the effect of heat upon the germination of conidia is not absolute in that some occurs in the absence of such treatment.

The results with conidia are at variance with those obtained by Mitchell (1957) who exposed conidia of strain $\mathrm{C}-102$ of Neurospora crassa to $60^{\circ} \mathrm{C}$. for 30,60 and 120 sec., at various times after the start of germination. Thus, when conidia were treated at $60^{\circ} \mathrm{C}$. for $30 \mathrm{sec}$., the percentage of survivors dropped from $100 \%$ to $2 \%$ after $2 \mathrm{hr}$. of incubation. These results are analogous, therefore, to the ones obtained with ascospores in the present work, but a direct comparison with the data on conidia is not possible because no heat-treatments at $60^{\circ} \mathrm{C}$. shorter than 5 -min. duration were administered.

\footnotetext{
Department of Botany

UNIVERSITY OF MichiGAN

Ann Arbor, Michigan
}

\section{LITERATURE CITED}

Arthik, J. C. 1929. The plant rusts. John Wiley and Sons, Inc. New York.

Biodgetr. E. C. 1935. Pathogenicity and physiology of Pseudopeziza ribis. Phytopath. 24: 6-7.

.... - 1936. The anthracnose of currant and gooseberry caused by Pseudopeziza ribis. Phytopath. 26: 115-152.

Cochrane, V. W. 1945. The effect of brief temperature treatment on germination of urediospores of Phrag. midium mucronatum (Fr.) Schlect. Phytopath. 35: $361-366$.

Donce, B. O. 1930. Breeding albinistic strains of the Monilia bread molds. Mycologia 22: 9-38.

Doran, W. L. 1922. Effect of external and internal factors on the germination of fungus spores. Bull. Torrey. Bot. Club. 49: 313-336.
Faull, Anna F. 1930. On the resistance of Neurospora crassa. Mycologia 22: 288-303.

Gäumanv, E. 1950. Principles of plant infection. Authorized English edition. Crosby Lockwood and Son, Ltd. London.

Gondard, D. R. 1935. The reversible heat activation in ducing sermination and increased respiration in the ascospores of Neurospora tetrasperma. Jour. Gen. Physiol. 19: 45-60.

..- And P. E. Smith. 1938. Respiratory block in the dormant ascospores of Neurospora tetrasperma. Plant Physiol. 24: 241-264.

Graf-Marin, A. 1934. Studies on powdery mildew of cereals. Cornell Univ. Agr. Exp. Sta. Mem. 157: $1-48$. 
Holton, R. 1958. Pyruvate metabolism and electron transport in Neurospora tetrasperma. Doctoral Thesis. Univ. of Michigan. Ann Arbor.

Ishil, R., And T. Miyamoto. 1954. Studies on the carotene production by microorganisms. VIII. Effect of previous heat treatment on the germination of conidia of Neurospora sitophila. Jour. Ferment. Technol. 22: $276-278$.

Kreitlow, K. W. 1943. Ustilago striieformis. II. Temperature as a factor infuencing development of smutted plants of Poa pratensis and germination of fresh chlamydospores. Phytopath. 33: 1055-1063.

Lingappa, B. T., And A. S. Sussman. 1959. Endogenous substrates of dormant, activated and germinating ascospores of Neurospora tetrasperma. Plant Physiol. (in press).

Lowry, R. J., and A. S. Sussman. 1958. Wall structure of ascospores of Neurospora tetrasperma. Amer. Jour. Bot. 45: 397-403.

Mitchell, H. K. 1957. Crossing over and gene conversion in Neurospora. In The chemical basis of heredity. McElroy, W. D., and B. Glass (Ed.). The Johns Hopkins Press, Baltimore.
Ryan, F. J. 1950. Selected methods of Neurosporu genetics. In Methods in medical research. Geraro, R. W. (Ed.). 3: 51-75. The Year Book Publishers, Inc. Chicago.

Shear, C. L., and B. O. Dodge. 1927. Life histories and heterothallism of the red bread-mold fungi of the Monilia sitophila group. Jour. Agric. Res. 34: 10191042.

Sussman, A. S. 1954. Changes in the permeability of ascopores of Neurospora tetrasperma during germination. Jour. Gen. Physiol. 38: 59-77.

… 1959. Spore germination in cryptogamic plants. In Encyclopedia of plant physiol. LaNG, A. (Ed.) Vol. 15. Springer-Verlag. Berlin. (In press).

— J. R. Distler, And J. S. Krakow. 1956. Metabolic aspects of Neurospora activation and germination. Plant Physiol. 31 : 126-135.

Tsaugi, H. 1933. Studies on the physiology of the conidiospores, conidia, and oospores of Sclerospora grami. nicola (Sacc.) Schroet. on the Japanese millet [Setaria graminicola (L.) Beauv.] Jour. Imp. Agric. Expt. Sta. 2: $225-252$.

\section{SEGREGATION AND RECOMBINATION OF CHEMICAL CONSTITUENTS IN A HYBRID SWARM OF BAPTISIA LAEVICAULIS $\times$ B. VIRIDIS AND THEIR TAXONOMIC IMPLICATIONS ${ }^{1}$}

\section{B. L. Turner and Ralph Alston}

\section{A B S T R A C T}

Turner, B. L. (U. Texas, Austin), and Ralph Alston. Segregation and recombination of chemical constituents in a hybrid swarm of Baptisia laevicaulis $\bar{X} \bar{B}$. viridis and their taxonomic implications. Amer. Jour. Bot. 46(9): 678-686. lllus. 1959.-Selected plants from a hybrid population of Baptisia laevicaulis $\times$ B. viridis and individuals from "pure" populations of the parental species were examined chromatographically. The resulting patterns were then compared with the respective phenotypes by the use of hybrid indices. Although the parental type individuals yielded nearly uniform patterns, hybrid-type plants showed a striking recombination of chemical components and there was an excellent correlation between chromatographic patterns and hybrid expression. Of particular interest was the detection of a new and distinctive compound in 2 of the hybrid-type plants which was not observed in either parent. Chromatograms of 3 other Baptisia species also showed distinctive patterns, and their relationship to each other, as indicated by morphological features, was accompanied by similarities in the biochemical pattern. The segregation and recombination of biochemical constituents are discussed with respect to their evolutionary and taxonomic implications. It is suggested that an extension of the techniques utilized might provide for the establishment of "biochemical profiles" which should prove of considerable value to the systematist.

The genus Baptisia (family Leguminosae) contains about 30 species widely distributed in the eastern United States. Larisey (1940a) has been the only recent monographer of the group, and in her treatment she has recognized a number of intraspecific taxa as well as several named hybrids. That hybridization is common between the various taxa may be inferred from the fact that Larisey recognized numerous cases of natural hybridization involving at least 8 different species.

${ }^{1}$ Received for publication May I, 1959.
In southeastern Texas, 4 well-marked species ( $B$. viridis, B. laevicaulis, B. leucantha, and B. nuttalliana) are frequently found growing together in various combinations and, in such cases, especially in disturbed habitats, hybridization is characteristic. A detailed morphological study of a hybrid swarm involving $B$. viridis and $B$. leucantha was reported by Larisey (1940b), and Turner (unpublished) has made a similar morphological study of hybrid swarms involving $B$. viridis and $B$. laevicaulis. Hybrid swarms between the latter species are particularly common and occur in varying degrees 